\title{
Enhancement of grade 7 students' performance in science through teacher-crafted worksheets
}

\author{
Perez, Janeth H. $\triangle$ \\ Calubcub 1.0 National High School, Batangas, Philippines (hernandezjaneth96@yahoo.com)
}

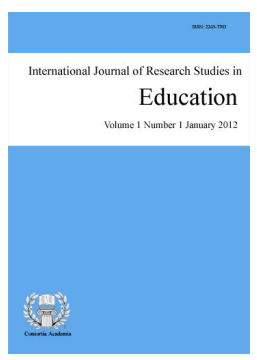

ISSN: 2243-7703 Online ISSN: 2243-7711

OPEN ACCESS

\section{Abstract}

This study aimed to develop, validate and determine the effectiveness of teacher-crafted worksheet in enhancing the learners' performance in science. The researcher made use of descriptive and experimental methods of research. Control and experimental classes were used in determining the effectiveness of the teacher-crafted worksheet in enhancing the learners' performance in science. Data collected were treated through the mean, weighted mean, standard deviation, and $t$-test. Finding revealed that the teachers and the students strongly agreed that the teacher-crafted worksheet was an effective tool to help improve the performance of the students; the achievement of the students in the experimental group who were exposed to the material is higher and better compared to the students taught in the traditional approach and there is a significant difference in the achievement level of the experimental group who utilized the worksheet and the controlled group who did not undergo the material.

Keywords: teacher-crafted worksheet; science process skills; performance; enhancement; action research 


\section{Enhancement of grade 7 students' performance in science through teacher-crafted worksheets}

\section{Introduction}

It is said that teaching is an art. Like all arts, the main actor spells the difference. In the art of teaching, the key person in the teaching-learning situation is the teacher for he is the director and facilitator of learning. For learning to take place, teachers have to teach. The teaching act is an interplay of a constellation of personality traits, teaching competencies, the theory/theories the teacher holds about learning as well as his assumption of the learners which springs them for teachers to have different teaching styles.

How may a student/learner begin to learn? What strategies can a teacher employ? What abilities will be useful for him? Learners whether slow or fast need careful and sympathetic teaching in science. Instead of trying to think of more labels for these learners-backward, retarded, less able, dull or gifted, teachers should start thinking of their needs. Learners in all abilities tend to be interested in practical works to develop new ideas on their own but most teachers struggle with the realization that their classroom contains students with wide range of skills, but they can teach to only one skill level at a time. Teachers constantly search for ways to program effectively for the entire range of student skills.

The researcher's teaching experience over a decade gave her awareness on the extent of educational challenges with regards to the teaching-learning process. Development of an effective instructional material to enhance the performance of the students arouses her interest and came up with this study.

\section{Background literature}

\subsection{The worksheets}

A worksheet, in the word's original meaning, is a sheet of paper on which one performs work. They come in many forms, most commonly associated with children's school work assignments, tax forms, and accounting or other business environments. Software is increasingly taking over the paper-based worksheet. It can be a printed page that a child completes with a writing instrument. No other materials are needed. It is "a sheet of paper on which work schedules, working time, special instructions, etc. are recorded. A piece or scrap of paper on which problems, ideas, or the like, are set down in tentative form." In education, a worksheet may have questions for students and places to record answers. Worksheet refers to a teaching aid introduced into the teaching methods to stimulate the activity of the students and thereby increased their level of understanding. It is strategically prepared and designed for teaching remediation for low achievers in the subject. It is given after the regular classroom instruction to students who were not able to grasp the concepts of the subject matter.

It is also defined worksheet as meant to re-teach the concepts and skills (least mastered). It is a material given to students to help them master competency - based skills which they were not able to develop during a regular classroom teaching. It consists of both learning strategies (for students) and content enhancement (for teachers). It is a multifaceted approach to help students to become independent and successful learners. It does not involve pretest and post-test and includes fun activities. Worksheet increases and deepens students' skills in manipulation, knowledge or thinking, understanding and observing the microscopic into macroscopic representation of matter like atoms, molecules and ions which students believe as a discrete representation of the existing matter and other related components of science.

The study on worksheet as a tool to reduce least mastered skills in Grade 4 Science, concluded that Teacher-crafted worksheet provides baseline information and should be implemented to avoid marginalization of 
pupils. The study also indicated that there is a significant reduction in the pupils' mean number of least mastered skills after Teacher-crafted worksheet implementation.

\subsection{Research questions}

This study aimed to develop, validate and determine the effectiveness of teacher-crafted worksheet in Science Grade 7, thus, attains growth in the learners' academic performance. Specifically, it attempted to answer the following questions:

$>\quad$ What is the result of the first quarter examination of grade seven students in Science at Calubcub 1.0 National High School based on the mean, Mean Percentage Score (MPS), standard deviation and item analysis for the school year 2018-2019?

$>$ How do students and teachers describe the, effectiveness of the teacher-crafted worksheet?

$>\quad$ What is the level of performance in the pre-test and post-test of the control and experimental group?

$>\quad$ Is there a significant difference in the achievement of students in the experimental and controlled groups?

\subsection{Scope and limitation}

Target respondents for the study were the grade seven students of Calubcub 1.0 National High School, San Juan, Batangas who got the lowest MPS during the first quarter examination on the academic year 2018-2019. All teachers and school head of the said school were also participants of this study. The student respondents were divided into two groups. Teacher-crafted worksheet was employed on the first group, while the other group was the control. This set of students underwent the traditional teaching method. All teachers, school head, and experimental group served as validators and evaluators of the material. Worksheet developed by the researcher and used by the respondents covered all the competencies in science.

\section{Methodology}

This study used the descriptive and experimental methods of research. The descriptive method was used in the preparation of the worksheets. The experimental method of research was used in evaluating the effectiveness of worksheets. According to Fraenkel and Wallen (2009), the experimental method of research is used for studying the selective effects of various treatment applied to a number of a sample or the same treatment applied to different members of different sample. This study employed the teacher-crafted worksheet to improve the performance of the grade seven students of Calubcub 1.0 National High School in science, school year 2018-2019.

\subsection{Sampling}

This study used two groups of students, the experimental and controlled groups. The experimental group subjected to teacher-crafted worksheet instruction while the controlled group is exposed to traditional method of teaching using the required textbook. The participants of the study were the two sections of Grade 7 students who got the lowest Mean Percentage Score (MPS) during the first quarter examination, all teachers and the school head of Calubcub 1.0 National High School in San Juan, Batangas during the school year 2018-2019. The student respondents were divided into controlled and experimental group. The teacher-crafted worksheet was employed in the experimental group. The controlled group was not given the materials.

\subsection{Data collection}

The teacher-crafted worksheets developed were evaluated and validated by the teachers of Calubcub 1.0 
National High School. The evaluation instrument which was written in English and was translated in Filipino consisted of fourteen statements that described the teacher-crafted worksheet in terms of the desired learning competencies; clarity of expression and explanation; provision of activities that match the learning objectives; organization of the content of the teacher-crafted worksheets; and relevance of life situation/environment. The students and teachers used the same questionnaire in evaluating the teacher-crafted worksheet.

The respondents had five options to select from in evaluating the teacher-crafted worksheet namely: strongly agree (5), agree (4), undecided (3), disagree (2) and strongly disagree (1). The respondents were asked to check the column that corresponds to their answer. To arrive at the verbal description of each item, the following arbitrary numerical guide was used:

$\begin{array}{cc}\text { Verbal Description } & \text { Numerical Guide } \\ \text { Strongly Agree } & 4.20-5.00 \\ \text { Agree } & 3.50-4.19 \\ \text { Undecided } & 2.60-3.49 \\ \text { Disagree } & 1.80-2.59 \\ \text { Strongly Disagree } & 1.00-1.79\end{array}$

The achievements of the student were determined using the pretest and posttest. The test was consisted of thirty-five items (multiple choice types). It was prepared by the researcher. It was administered before and after the intervention to both experimental and controlled groups. The test items were based on the desired learning competencies for the topics on the first quarter.

\subsection{Ethical issues}

Permit to conduct the study was asked from the persons of authority. The confidentiality of the results of the assessment was kept.

\subsection{Plan for data analysis}

The statistical tools used were the Mean Percentage Score (MPS), mean, weighted mean, standard deviation and t-test. Mean Percentage Score (MPS) was used to determine the result of the first quarter examination in Science for the school year 2018-2019. Mean was used to determine the mastery level of the students in each of the item in the first quarter examination during the item analysis. It is also used to determine where most of the scores of the students clustered. Weighted mean was used in evaluating the teacher-crafted worksheets. Standard deviation was used to determine the variability of the students' abilities or scores. The mean was subtracted from the students' scores. The difference was squared after which the summation was obtained. T-test was used in establishing differences in the post test. Scores significant level was set at .05.

\section{Results and findings}

\section{Table 1}

Descriptive statistics for the First Quarter Examination in Science grade 7

\begin{tabular}{|c|c|c|c|}
\hline Grade and Section & Mean & $M P S$ & $S D$ \\
\hline 7-Sampaguita & 33.84 & 56.40 & 7.97 \\
\hline 7-Rose & 20.47 & 34.12 & 7.46 \\
\hline 7-Ilang-Ilang & 23.56 & 39.27 & 6.31 \\
\hline 7-Rosal & 22.53 & 37.55 & 7.58 \\
\hline Average & 25.10 & 41.84 & 7.33 \\
\hline
\end{tabular}

Table 1 shows the mean, Mean Percentage Score (MPS) and standard deviation of the first quarterly examination conducted on August 9-10, 2018. According to the data, among the four sections of grade 7 students at Calubcub 1.0 National High School, 7-Rosal and 7-Rose ranked third and fourth respectively in terms of MPS.

16 Consortia Academia Publishing (A partner of Network of Professional Researchers and Educators) 
All sections were not able to meet the standard but the two sections with the lowest MPS were the respondents of this study. They were divided into experimental group and controlled group. It could be concluded that the performance level of the students at Calubcub 1.0 National High School for the first quarter examination was below the standard which is $75 \%$.

The science teacher must design a learning experience which will attend to three domains. Science students must have an understanding of and a commitment to the requisite conditions for meaningful learning. Novak's theory gives the "irreducible commonplace" the evaluation. Evaluation is obviously important in measuring learning outcomes. Test will assess students' cognitive, practical and social skills. Therefore, the results in the periodic test clearly show whether the students have gained and mastered the skills in a particular subject.

Table 2

Item analysis of the first quarter examination in science grade 7

\begin{tabular}{|c|c|c|c|}
\hline Item No. & No. of Correct Responses & $\%$ of Correct Responses & Remarks \\
\hline 1 & 176 & 79.64 & $\mathrm{M}$ \\
\hline 2 & 116 & 52.49 & NM \\
\hline 3 & 102 & 46.15 & Not M \\
\hline 4 & 123 & 55.66 & NM \\
\hline 5 & 97 & 43.89 & Not M \\
\hline 6 & 59 & 26.70 & Not M \\
\hline 7 & 128 & 57.92 & NM \\
\hline 8 & 82 & 37.10 & Not M \\
\hline 9 & 123 & 55.66 & NM \\
\hline 10 & 138 & 62.44 & NM \\
\hline 11 & 94 & 42.53 & Not M \\
\hline 12 & 157 & 71.04 & NM \\
\hline 13 & 112 & 50.68 & NM \\
\hline 14 & 119 & 53.85 & NM \\
\hline 15 & 128 & 57.92 & NM \\
\hline 16 & 113 & 51.13 & NM \\
\hline 17 & 86 & 38.91 & Not M \\
\hline 18 & 102 & 46.15 & Not M \\
\hline 19 & 71 & 32.13 & Not M \\
\hline 20 & 115 & 52.04 & NM \\
\hline 21 & 51 & 23.08 & Not M \\
\hline 22 & 76 & 34.39 & Not M \\
\hline 23 & 62 & 28.05 & Not M \\
\hline 24 & 93 & 42.08 & Not M \\
\hline 25 & 96 & 43.44 & Not M \\
\hline 26 & 145 & 65.61 & NM \\
\hline 27 & 107 & 48.42 & Not M \\
\hline 28 & 101 & 45.70 & Not M \\
\hline 29 & 78 & 35.29 & Not M \\
\hline 30 & 104 & 47.06 & Not M \\
\hline 31 & 118 & 53.39 & NM \\
\hline 32 & 137 & 61.99 & NM \\
\hline 33 & 135 & 61.09 & NM \\
\hline 34 & 140 & 63.35 & NM \\
\hline 35 & 93 & 42.08 & Not M \\
\hline 36 & 67 & 30.32 & Not M \\
\hline 37 & 108 & 48.87 & Not M \\
\hline 38 & 127 & 57.47 & NM \\
\hline 39 & 79 & 35.75 & Not M \\
\hline 40 & 112 & 50.68 & NM \\
\hline
\end{tabular}


Perez, J. H.

Table 2 ...continued

\begin{tabular}{cccc}
\hline Item No. & No. of Correct Responses & \% of Correct Responses & Remarks \\
\hline 41 & 102 & 46.15 & Not $\mathrm{M}$ \\
42 & 91 & 41.18 & Not $\mathrm{M}$ \\
43 & 63 & 28.51 & Not $\mathrm{M}$ \\
44 & 109 & 49.32 & Not $\mathrm{M}$ \\
45 & 69 & 31.22 & Not $\mathrm{M}$ \\
46 & 65 & 29.41 & Not $\mathrm{M}$ \\
47 & 95 & 42.99 & Not $\mathrm{M}$ \\
48 & 86 & 38.91 & Not $\mathrm{M}$ \\
49 & 78 & 35.29 & Not $\mathrm{M}$ \\
50 & 106 & 47.96 & Not $\mathrm{M}$ \\
51 & 84 & 38.01 & Not $\mathrm{M}$ \\
52 & 77 & 34.84 & Not $\mathrm{M}$ \\
53 & 64 & 28.96 & Not $\mathrm{M}$ \\
54 & 96 & 43.44 & Not $\mathrm{M}$ \\
55 & 112 & 50.68 & NM \\
56 & 70 & 31.67 & Not $\mathrm{M}$ \\
57 & 60 & 27.15 & Not $\mathrm{M}$ \\
58 & 132 & 59.73 & NM \\
59 & 68 & 30.77 & Not $\mathrm{M}$ \\
60 & 91 & 41.18 & Not $\mathrm{M}$ \\
\hline Legend: & $1-49.99$ - Not Mastered (Not M), 50-74.99- Nearing Mastery (NM), and 75-100 - Mastered (M).
\end{tabular}

Based on the table, out of sixty items, one skill was mastered, 20 items got nearing mastery level and 39 items were not mastered. It was implied that performance of the learners should be improved in school year 2018-2019. This implies that the students did not master the skills needed in the subject to attain a 75 percent performance level. Hence, the science teacher must provide a learning experience for the students which will attend to the three domains. This fact is supported by the Transformation Learning Theory of Wink (2001), that it is important for science educators to recognize the fact that a student who cannot solve certain problems is one who lacks particular knowledge.

\subsection{Students' and teachers' description of the effectiveness of the teacher-crafted worksheet}

This part presents the students and teachers description of the effectiveness of the teacher-crafted worksheet in enhancing the performance of the students.

\section{Table 3}

Students' description of the teacher-crafted worksheet in science

\begin{tabular}{lcc}
\multicolumn{1}{c}{ Statements } & Weighted Mean & Verbal Description \\
\hline 1. The objectives are specific, measurable, attainable, realistic & 4.87 & Strongly Agree \\
and time-bound. & \\
(Ang mga layunin ay tiyak, nasusukat, naaabot, makatotohanan, & \\
at may tiyak na panahong saklaw.) & \\
\hline 2. Through the Teacher-crafted worksheet the students are able to & 4.67 & Strongly Agree \\
observe independence and self-confidence. & \\
(Sa pamamagitan ng $T W$, makakagawa ang mga mag-aaral nang & \\
may kalayaan at tiwala sa sarili.) & \\
\hline 3. The Teacher-crafted worksheet helps the learners to think & \\
logically and critically. & \\
(Makatutulong ang TW upang makapag-isip nang makatuturan & \\
at mapanuri ang mga mag-aaral.) & \\
\hline 4. The stated objectives are relevant to the students' needs. & \\
(Ang mga layunin ay makabuluhan at naaayon sa & \\
pangangailangan $n g$ mga mag-aaral.) & & Strongly Agree \\
\hline
\end{tabular}

18 Consortia Academia Publishing (A partner of Network of Professional Researchers and Educators) 
Enhancement of grade 7 students' performance in science through teacher-crafted worksheets

Table 3 ...continued

\begin{tabular}{|c|c|c|}
\hline Statements & Weighted Mean & Verbal Description \\
\hline $\begin{array}{l}\text { 5. The given activities are enough to enable the students to } \\
\text { understand the lesson. } \\
\text { (Ang mga ibinigay na gawain ay sapat upang ganap na } \\
\text { maunawaan ng mga mag-aaral ang aralin.) }\end{array}$ & 4.38 & Strongly Agree \\
\hline $\begin{array}{l}\text { 6. The discussion of the lesson is simple and clear. } \\
\text { (Payak at malinaw ang pagtalakay sa mga aralin.) }\end{array}$ & 4.62 & Strongly Agree \\
\hline $\begin{array}{l}\text { 7. The language of the Teacher-crafted worksheet is clear and } \\
\text { simple. } \\
\text { (Payak at malinaw ang mga salitang ginamit sa } T W . \text { ) }\end{array}$ & 4.77 & Strongly Agree \\
\hline $\begin{array}{l}\text { 8. The writing style of the Teacher-crafted worksheet makes it } \\
\text { enjoyable to read. } \\
\text { (Naging kasiya-siya ang pagbabasa ng Teacher-crafted } \\
\text { worksheet dahil sa malikhainh paraan ng pagkakasulat nito. }\end{array}$ & 4.84 & Strongly Agree \\
\hline $\begin{array}{l}\text { 9. The guide questions at the end of each activity reinforce the } \\
\text { basic concepts in the properties and the preparation of } \\
\text { Teacher-crafted worksheet. } \\
\text { (Ang mga gabay na tanong sa hulihan ng bawat gawain ay } \\
\text { nagpapatibay sa mga pangunahing konsepto ng mga katangian } \\
\text { at paghahanda ng Teacher-crafted worksheet.) }\end{array}$ & 4.88 & Strongly Agree \\
\hline $\begin{array}{l}\text { 10. The questions at the test reflect the behavioral objectives in } \\
\text { the Teacher-crafted worksheet. } \\
\text { (Ang mga tanong sa mga pagsusulit ay akma sa mga layunin ng } \\
\text { Teacher-crafted worksheet.) }\end{array}$ & 4.80 & Strongly Agree \\
\hline $\begin{array}{l}\text { 11. The organization of the lesson is logical and properly } \\
\text { sequenced. } \\
\text { (Ang kaayusan ng mga aralin ay makatuwiran at may tamang } \\
\text { pagkakasunud-sunod.) }\end{array}$ & 4.83 & Strongly Agree \\
\hline $\begin{array}{l}\text { 12. The lesson is relevant and suited to the learner's level of } \\
\text { mental development. } \\
\text { (Nauugnay at nababagay ang aralin sa antas ng kaisipan ng mga } \\
\text { mag-aaral.) }\end{array}$ & 4.69 & Strongly Agree \\
\hline $\begin{array}{l}\text { 13. The Teacher-crafted worksheet is functional and relevant. } \\
\text { (Makabuluhan at nagagamit ang Teacher-crafted worksheet.) }\end{array}$ & 4.90 & Strongly Agree \\
\hline $\begin{array}{l}\text { 14. The illustration used is simple, correct and makes the } \\
\text { procedure more understandable. } \\
\text { (Ang mga larawang ginamit ay payak, tama at } \\
\text { nakapagpapadaling unawain ang mga pamamaraan.) }\end{array}$ & 4.89 & Strongly Agree \\
\hline
\end{tabular}

As shown in table 3, student respondents strongly agreed that the Teacher-crafted worksheet is functional and relevant, 4.90; the illustration used is simple, correct and makes the procedure more understandable, 4.89; the guide questions at the end of each activity reinforce the basic concepts in the properties and the preparation of Teacher-crafted worksheet, 4.88; the objectives are specific, measurable, attainable, realistic and time-bound, 4.87; the writing style of the Teacher-crafted worksheet makes it enjoyable to read, 4.84; the organization of the lesson is logical and properly sequenced, 4.83; the questions at the test reflect the behavioral objectives in the Teacher-crafted worksheet, 4.80; the stated objectives are relevant to the students' needs, 4.78; the language of the Teacher-crafted worksheet is clear, 4.77; the Teacher-crafted worksheet helps the learners to think logically and critically, 4.74; the lesson is relevant and suited to the learner's level of mental development, 4.69; through the Teacher-crafted worksheet the students are able to observe independence and self-confidence, 4.67; the discussion of the lesson is simple and clear, 4.64; and the given activities are enough to enable the students to understand the lesson, 4.38 .

This is also found similar to the study of Caculitan (2000) wherein the prepared instructional material was rated excellent by the teacher- evaluators in terms of overview, objectives, topics, activities and evaluation 
materials, thus the said instructional material was found curricularly valid hence, it could be used as instructional material in the classroom.

\section{Table 4}

Teachers' description of the effectiveness of the teacher-crafted worksheet

\begin{tabular}{|c|c|c|}
\hline Statements & Weighted Mean & Verbal Description \\
\hline $\begin{array}{l}\text { 1. The objectives are specific, measurable, attainable, realistic and } \\
\text { time-bound. } \\
\text { (Ang mga layunin ay tiyak, nasusukat, naaabot, makatotohanan, at } \\
\text { may tiyak na panahong saklaw.) }\end{array}$ & 4.86 & Strongly Agree \\
\hline $\begin{array}{l}\text { 2. Through the Teacher-crafted worksheet the students are able to } \\
\text { observe independence and self-confidence. } \\
\text { (Sa pamamagitan ng Teacher-crafted worksheet, makakagawa ang } \\
\text { mga mag-aaral nang may kalayaan at tiwala sa sarili.) }\end{array}$ & 4.83 & Strongly Agree \\
\hline $\begin{array}{l}\text { 3. The Teacher-crafted worksheet helps the learners to think logically } \\
\text { and critically. } \\
\text { (Makatutulong ang Teacher-crafted worksheet upang makapag-isip } \\
\text { nang makatuturan at mapanuri ang mga mag-aaral.) }\end{array}$ & 4.86 & Strongly Agree \\
\hline $\begin{array}{l}\text { 4. The stated objectives are relevant to the students' needs. } \\
\text { (Ang mga layunin ay makabuluhan at naaayon sa pangangailangan } \\
\text { ng mga mag-aaral.) }\end{array}$ & 5.00 & Strongly Agree \\
\hline $\begin{array}{l}\text { 5. The given activities are enough to enable the students to } \\
\text { understand the lesson. } \\
\text { (Ang mga ibinigay na gawain ay sapat upang ganap na maunawaan } \\
\text { ng mga mag-aaral ang aralin.) }\end{array}$ & 4.86 & Strongly Agree \\
\hline $\begin{array}{l}\text { 6. The discussion of the lesson is simple and clear. } \\
\text { (Payak at malinaw ang pagtalakay sa mga aralin.) }\end{array}$ & 5.00 & Strongly Agree \\
\hline $\begin{array}{l}\text { 7. The language of the Teacher-crafted worksheet is clear and } \\
\text { simple. } \\
\text { (Payak at malinaw ang mga salitang ginamit sa Teacher-crafted } \\
\text { worksheet.) }\end{array}$ & 4.93 & Strongly Agree \\
\hline $\begin{array}{l}\text { 8. The writing style of the Teacher-crafted worksheet makes it } \\
\text { enjoyable to read. } \\
\text { (Naging kasiya-siya ang pagbabasa ng Teacher-crafted worksheet } \\
\text { dahil sa malikhainh paraan ng pagkakasulat nito. }\end{array}$ & 4.93 & Strongly Agree \\
\hline $\begin{array}{l}\text { 9. The guide questions at the end of each activity reinforce the basic } \\
\text { concepts in the properties and the preparation of Teacher-crafted } \\
\text { worksheet. } \\
\text { (Ang mga gabay na tanong sa hulihan ng bawat gawain ay } \\
\text { nagpapatibay sa mga pangunahing konsepto ng mga katangian at } \\
\text { paghahanda ng Teacher-crafted worksheet.) }\end{array}$ & 4.93 & Strongly Agree \\
\hline $\begin{array}{l}\text { 10. The questions at the test reflect the behavioral objectives in the } \\
\text { Teacher-crafted worksheet. } \\
\text { (Ang mga tanong sa mga pagsusulit ay akma sa mga layunin ng } \\
\text { Teacher-crafted worksheet.) }\end{array}$ & 4.90 & Strongly Agree \\
\hline $\begin{array}{l}\text { 11. The organization of the lesson is logical and properly sequenced. } \\
\text { (Ang kaayusan ng mga aralin ay makatuwiran at may tamang } \\
\text { pagkakasunud-sunod.) }\end{array}$ & 5.00 & Strongly Agree \\
\hline $\begin{array}{l}\text { 12. The lesson is relevant and suited to the learner's level of mental } \\
\text { development. } \\
\text { (Nauugnay at nababagay ang aralin sa antas ng kaisipan ng mga } \\
\text { mag-aaral.) }\end{array}$ & 5.00 & Strongly Agree \\
\hline $\begin{array}{l}\text { 13. The Teacher-crafted worksheet is functional and relevant. } \\
\text { (Makabuluhan at nagagamit ang Teacher-crafted worksheet.) }\end{array}$ & 4.97 & Strongly Agree \\
\hline
\end{tabular}


Enhancement of grade 7 students' performance in science through teacher-crafted worksheets

Table 4 ...continued

\begin{tabular}{lcc}
\hline \multicolumn{1}{c}{ Statements } & Weighted Mean & Verbal Description \\
\hline 14. The illustration used is simple, correct and makes the procedure & 5.00 & Strongly Agree \\
more understandable. & \\
(Ang mga larawang ginamit ay payak, tama at nakapagpapadaling & \\
unawain ang mga pamamaraan.) & \\
\hline $\begin{array}{l}\text { Legend: } 4.20 \text { - 5.00 - strongly agree, } 3.40-4.19-\text { agree, } 2.60-3.39 \text { - moderately agree, } 1.80-2.59-\text { disagree, and } 1.00-1.79-\text { strongly } \\
\text { disagree. }\end{array}$
\end{tabular}

Table 4 presents that with regards to the effectiveness of Teacher-crafted worksheet, teachers perfectly agreed that the stated objectives are relevant to the students' needs; the discussion of the lesson is simple and clear; the organization of the lesson is logical and properly sequenced, 5.00; the lesson is relevant and suited to the learner's level of mental development and the illustration used is simple, correct and makes the procedure more understandable, 5.00 .

Furthermore, they strongly agreed that the Teacher-crafted worksheet is functional and relevant, 4.97, the language of the Teacher-crafted worksheet is clear, 4.93; the writing style of the Teacher-crafted worksheet makes it enjoyable to read, 4.93; the guide questions at the end of each activity reinforce the basic concepts in the properties and the preparation of Teacher-crafted worksheet,4.93; the questions at the test reflect the behavioral objectives in the Teacher-crafted worksheet, 4.90; the objectives are specific, measurable, attainable, realistic and time-bound, 4.86; the Teacher-crafted worksheet helps the learners to think logically and critically, 4.86; the given activities are enough to enable the students to understand the lesson, 4.86 and through the Teacher-crafted worksheet, the students are able to observe independence and self-confidence, 4.83 .

\subsection{Level of performance in the pre-test and post-test of the controlled and experimental group}

This part shows the level of performance of the control group who was not given the material and the experimental group who utilized the Teacher-crafted worksheet.

\section{Table 5}

Pretest and posttest of the controlled and experimental group

\begin{tabular}{ccccc}
\hline & \multicolumn{2}{c}{ Controlled Group } & \multicolumn{2}{c}{ Experimental Group } \\
\cline { 2 - 5 } Statistical Tool & Pretest & Posttest & Pretest & Posttest \\
\hline Mean & 12.68 & 15.17 & 10.02 & 24.40 \\
MPS & 36.23 & 43.34 & 28.63 & 69.70 \\
SD & 3.48 & 4.44 & 3.05 & 4.50 \\
\hline
\end{tabular}

Table 5 shows that control group got a higher Mean Percentage Score than the experimental group during the pretest. This means that the experimental group knew a little lesser than the controlled group with regards to the topics covered for the first quarter. However, the experimental group got the higher MPS than the control group during the posttest after they were exposed to the Teacher-crafted worksheet. It was implied that experimental group performed better than the control group through the Teacher-crafted worksheet.

\subsection{Comparison of the achievement level of the experimental and the controlled group}

Table 6 presents the data and the discussions of the difference in the achievement level of the experimental and the controlled group with regards to the effectiveness and utilization of Teacher-crafted worksheet. The result of this study would of significant to the school administrators in designing trainings/seminars on preparation of quality instructional materials. The worksheet that was originally developed by the researcher could also be of help to other teachers in science. The $t$ computed value was -8.677 is less than $\mathrm{t}$ critical value which means that there is a significant difference in the achievement level of the experimental and the controlled group. Teacher-crafted worksheet was an effective tool in enhancing the science process skills of the learners. 


\section{Table 6}

T-table of the achievement level of the experimental and controlled group

\begin{tabular}{ccc}
\hline Statistics & Controlled Group & Experimental Group \\
\hline Mean & 15.17 & 24.40 \\
Variance & 19.7136 & 20.25 \\
Observations & 53 & 53 \\
$d f$ & 0 & \\
$t$ Stat & 104 & \\
$p(\mathrm{~T}<=\mathrm{t})$ one-tail & -8.679 & \\
$\mathrm{t}$ Critical one-tail & 1.6596 & \\
$p \mathrm{pP}(\mathrm{T}<=\mathrm{t})$ two-tail & 2.36274 & \\
$t$ Critical two-tail & 1.98304 & \\
\hline
\end{tabular}

\section{Conclusions}

Based on the findings of the study cited above, the researcher arrived on the following conclusions:

$>$ The performance level in Science of the grade 7 students at Calubcub 1.0 National high School is low.

$>$ Teacher-crafted worksheet should be developed to enhance the performance of the students for all the competencies covered in the first quarter.

$>\quad$ Teachers and students found the Teacher-crafted worksheet effective and efficient in enhancing the performance of the students with low mastery level.

$>$ Teacher-crafted worksheet was an effective tool to improve the performance of the students with low mastery level.

$>$ There is a significant difference in the performance of the experimental and the control group.

\subsection{Recommendations}

Considering the conclusions extracted from the findings, the following recommendations are offered:

$>$ Performance of the students in the quarterly examination must be improved.

$>$ Teacher-crafted worksheet must be developed in all learning areas.

$>$ Teacher-crafted worksheet must be given to the students with a low performance.

$>$ School administrators must encourage the teachers to develop Teacher-crafted worksheet not only in Science but in all subject areas.

$>$ Teacher-crafted worksheet preparation must be a part of the teachers' training for its effectiveness in enhancing learners' performance.

\section{References}

Caculitan, E. P. (2000). A college resource book in earth science: Its utilization and effectiveness [Doctoral Dissertation]. University of Saint Anthony, City of Iriga.

Fraenkel, J. R., \& Wallen, N. E. (2009). How to design and evaluate research in education. New York, NY: McGraw-Hill

Wink, D. J. (2001). Reconstructing student meaning: A theory of perspective transformation. Journal of Chemical Education, 78(8). https://doi.org/10.1021/ed078p1107.8 